\title{
6 Organizational Change and Work Spirituality: Expanding the Moral Circle
}

Work spirituality is a broad academic tent under which two rather different 'camps' gather. On one side there are scholars and practitioners wishing to measure and augment the "spiritual capital" of organizations in order to foster innovation, efficiency and profits (Zohar \& Marshall, 2004); on the other those who advocate for the betterment of the human condition in organizations and a re-enchantment of nature beyond any instrumental reasons (Bøje et al., 2012); Case \& Gosling, 2010). The ones, the 'instrumentalists,' advance the business case for spirituality; the others, the 'critical spiritualists,' advance instead a spiritual case for business, which would lose legitimacy if it prevented the spiritual flourishing of individuals and communities. Organizational change is framed in the two camps according to an analogous epistemological-axiological difference, the ones aiming at identifying objective best practice examples of "spiritual organizations" leading to higher efficiency and profits (Mitroff \& Denton, 1999), the others studying the role of spiritual leadership and practices to emancipate individuals within communities in organizations (Dent et al., 2005; Mabey \& Mayrhofer, 2015). What is common to the two camps is their teleological and activist flavor evident in the belief that, by aligning the spiritual values of the employees to those of the organization or by elevating their spiritual awareness, positive change will almost spontaneously come true (Dehler \& Welsh, 1994).

We share Case and Gosling's (2010, p. 276) preoccupation that the spiritual organization, as an instrumentalist ideal type, risks "representing a sinister attempt on the part of capitalist organizations to harness, manipulate and control the soul of employees." Our aim in this chapter is thus to contribute to the critical spiritualist discussion in its attempt to "seek more transformative connections ... with nature and with the planet" (Neal, 2013a, p. 735) and in its pursuit of a "non-anthropocentric ethics" (Gosling \& Case, 2013). Within this research program, however, we recognize a blind spot. In the purportedly non-anthropocentric flight forward towards a "posthumanist approach" for the re-enchantment of an undefined nature (Bøje, 2012, p. 266) we risk disregarding the trees for the forest.

The 'trees' are billions of individual sentient beings exposed to terrible suffering and painful death amassed in factory farms (Lever \& Evans, 2017). We agree with Taylor and Bell (2012, p. 569) that "spirituality must be made to work within but against modernity, challenging and transcending the foundations of efficiency and calculability that are inherent to disenchanted organizational norms" and consider nonhuman animals (NHAs) to be victims of a modernist system of objectification that transforms them into raw materials to be efficiently processed 
(Fischer, 2020). In these firms, NHAs are considered like machines producing under a pure economic logic goods for human consumption despite the fig leave offered by marginal welfare improvements within organic and 'humane' protocols (Lever \& Evans, 2017). The new generations, the millions of children and young adults who woke up politically to fight against climate change have mostly embraced a plantbased diet following scientific evidence on the negative climate effects of animal products (Willett et al., 2019) and a moral repulsion towards the mainstream practices in animal husbandry (Elder, 2020). This generation, soon equipped with higher negotiation power due to current demographic trends (Goodhart \& Pradhan, 2017), is entering organizations and increasingly pushing for change, e.g., not only plantbased food in canteens but a whole different approach to our relationship with NHAs. The field of workplace spirituality cannot remain deaf, as it mainly has so far, to this spiritual awakening that is expanding the moral circle to include NHAs seen in their individuality - not just part of an undefined 'nature' or members of species whose biodiversity we must protect for anthropocentric reasons. This new expanded sensitivity to suffering and compassion goes hand in hand with spiritual practices such as meditation and community exchange interestingly combined more with rationality and science than with religion.

The purpose of this chapter is hence not only to offer a bird's eye view on the understanding of organizational change within workplace spirituality literature and on the reception of work spirituality within the organizational change literature, but also to point to the need for future research in addressing the role of NHAs in contemporary organizations. In the following, we first discuss the sparce reception of workplace spirituality in organizational change by analyzing two important handbooks and two specialized journals. We then analyze two work spirituality handbooks and the Journal of Management, Spirituality and Religion (JMSR) to ascertain how organizational change is treated in this field. Further, we focus on how the relationship between human and nonhuman animals has been framed and theorized within the workplace spirituality literature. Finally, we sustain that "care, compassion and support of others" (MSR Division, 2018, p. 2) would require the recognition of suffering as a common experience across the species including sentient NHAs among the "others" for whom we should feel compassion. We advance that such extended care and compassion, as well as a longtermist ethical approach, should be adopted in the quest for the universalizing stage of spiritual development (Fowler, 1981). We complement these considerations with personal observations derived from our own involvement as participants or researchers in climate movements. 


\section{Workplace Spirituality in the Organizational Change Literature}

The Journal of Organizational Change Management is a primary outlet also for the work spirituality field. This overlapping in readership would suggest a strong integration of the topics of change and spirituality, but the journal is a place where scholars of both fields publish maintaining mostly the disciplinary distinction. We found indeed 208 articles with the search term "spiritual*”. However, as the topics refer to mindfulness practices, spiritual capital measures, authentic leadership or leadership for sustainability, they do not directly address organizational change as usually understood, i.e., "organizational change as a difference in form, quality, or state over time in an organizational entity" (Poole \& Van de Ven, 2004, p. xi). Searching within these articles for the word 'change' in the title and abstract we could only find Long and Mills (2010) theoretical paper, that address organizational change in some more substantial way. The authors offer a critique of an instrumental interpretation and use of workplace spirituality as a means to achieve material gains by forging a more performing common culture. When framed instrumentality, Long and Mills (2010) argue, workplace spirituality becomes a subtle tool for imposing managers' values on employees, trying to control their minds and devaluing opportunities of spiritual self-realization outside of the organizational context. For them, a project of critical spirituality should develop "the capacity to operate within the context of diverse values, rather than try to operate from the misguided belief that spiritual values will unify the organization" (p. 337). Long and Mills (2010, p. 338), hence, consider the project of introducing spirituality at work ethically justified only if it aims at promoting "an elevated social consciousness necessary to reconstruct the workplace in a manner that challenges the structural inequalities, exploitive tendencies, unsustainability and marginalization produced by modern managerial practices in the pursuit of material gain."

In the Journal of Change Management, sixteen articles include the word "spiritual ${ }^{\star}$ " but few of them treat the topic in a more substantial way. Apart from articles that address the spiritual component of transformative leadership (Gill, 2002), or that mention spirituality in passing while framing the need for organizational change to reach system level in order to address climate sustainability (Benn \& Baker, 2009), notable is Boje's (2012) call for a new ontology that considers our interconnection with nature. However, the main attention to spirituality in this journal comes from practitioners, consultants, or management gurus like Scharmer (2020). The debate on Scharmer's "Theory U” as a practical change management approach or as an "esoteric" management fashion also addresses this (Kühl, 2020). Scharmer's Theory U focuses on community, self-transcendence and awareness, i.e., a terminology close to the spiritual vocabulary. It states the explicit need for society to transform itself to overcome "spiritual disruption" referring to mindfulness practices as "new methods 
and tools that help leaders and change-makers create containers for evolving the self, i.e. for shifting the awareness in a system from ego to eco" (Scharmer, 2020, p. 329).

The analysis of The Routledge Companion to Organizational Change edited by David M. Boje, Bernard Burnes and John Hassard (2012) let the following topics emerge. The chapter by Bushe (2012) on Cooperrider's Appreciative Inquiry (AI) refers to what seems to be the first consideration of spirituality in the organizational change discipline. AI is centered on discovering what "gives life" to any organizational system and in this "might be considered a spiritual practice" (Bushe, 2012, p. 94). And indeed, in a recent interview with Sandra Waddock (2015, p. 164, passim), Cooperrider himself emphasizes that the spiritual underpinnings of AI are aimed at appreciating “the miracle of life" inspired by Albert Schweitzer's book Reverence for Life. For Schweitzer (1947; cit. by Kawall, 2003, p. 340), who was inspired by the Janisim's concept of ahimsa (non-violence towards every being), reverence for life affords the "fundamental principle of morality, namely that good consists in maintaining, assisting and enhancing life, and that to destroy, to harm, or to hinder life, is evil." Cooperrider's spiritual position grounds a meta-ethic that combines ontological, epistemological and ethical stances: the social world is a miracle of cooperation, science should be generative, and "we need a reconnection with the miracle of life on this planet, where we see things again in living systems, alive and miraculous and filled with emergent potential" (interview with Waddock, 2015, p. 249). In a similar vein, Boje (2012, p. 520), reconnects to some of these ideas about the ontology of our world and prefigures "a future that is about ecological sustainability and ontic ties to nature" and of "rediscovering enchantment [of] . . . the natured world", in what he calls a "posthumanist approach."

One entire chapter of this Companion is devoted to the relationship between spirituality at work and organizational change (Taylor \& Bell, 2012). The authors define spirituality at work as a movement aimed at re-enchanting our organizations made meaningless by the dominance of a purely instrumental rationality. Given the level of disenchantment and the instrumentality of managerial approaches to organizational culture, only a transformational approach can have an effect against the total absence of metaphysical and transcendent issues speaking to the magic, mystery, or enchantment of our social and personal worlds. However, they also point to the risk that this movement could merely produce a 'disenchanted re-enchantment'. Its modernist approaches might be hijacked by management and transformed into a "a means of colonizing the self in a way which extends ever deeper into individual subjectivities" (p. 571). They conclude with a more positive, although paradoxical, take on the role of spirituality in our organizations: "spiritualities enable the development of subjects who are able to reconcile reason and emotion, remaining relational and attached while simultaneously rooted in enlightenment norms of critical thinking” (Taylor \& Bell, 2012, p. 576). 
In the 2004 edition of the Oxford Handbook of Organizational Change and Innovation edited by Marshall Scott Poole and Andrew Van de Ven, there is no mention of work spirituality, and religion was mentioned only as an institutional logic. In the $2^{\text {nd }}$ edition, schedule to be published in mid-2021, workplace spirituality, judging from the authors and table of contents, again doesn't seem to receive consideration. We now turn to an analysis of how organizational change ideas, theories and methods were received within the work spirituality literature.

\section{Organizational Change in Work Spirituality Literature}

Although change is ubiquitous in the Handbook of Faith and Spirituality in the Workplace edited by Judi Neal (2013c), it is here mainly meant in the sense of transformative spiritual change that is supposed to have positive effects on organizations. Similarly, change is conceived in the sense of a movement towards a "a spiritually rich and spiritually friendly workplace” by Stoner (2013, p. 495). A chapter by Russell (2013) on spiritual leadership touches upon the role of leaders as spiritual change agents. Stead and Stead (2013, p. 271) focus on the transformative role of spirituality to empower change towards sustainability and "the creation of spiritual capital in organizations, a kind of wealth earned by serving humankind and the planet." Major (2013) describes the downsizing and change of a division at Hewlett-Packard and uses work spirituality vocabulary such as "belonging" (community), "purpose” (meaning) and “transcendence." Waddock and Steckler (2013, p. 287) investigate the role of wisdom and spirituality to ground valuable social entrepreneurship towards the challenges of our times such as "climate change and lack of sustainability, population growth and inequity, and food, security, and energy crises." They envision disruptive social change agents working towards systemic social change by challenging existing business models.

In the Palgrave Handbook of Workplace Spirituality and Fulfillment edited by Satinder Dhiman, Gary Roberts and Joanna Crossman (2018), organizational change or change management are mentioned in ten chapters, but mostly tangentially, e.g., servant leadership, individual spirituality and mindfulness practices are considered in different chapters as conducive to greater engagement and as preconditions for effective organizational change. Only in three chapters there is a broader and more original treatment. Bucci (2018) suggests an interesting scriptural approach to change management based on the transposition of reflections by Christian authors on the process of individual conversion. His central idea is that sustainable change can only occur if individuals go through a process of conversion led by deeply held spiritual values and translates this insight into a stage model for change. Neal (2018) refers in her overview of workplace spirituality research to Dehler and Welsh's (1994) integration of Porras 
and Silvers' (1991) model of organizational transformation with the notions of emotion and spirituality going beyond the purely cognitive focus of organizational development. Finally, Burton, Jeong and Saini (2018, p. 3) address the problem of "dark spirituality", a situation where "a state of darkness that 'masquerades' as good . . . ultimately works against the growth and development of an organization and the common good."

In the Journal of Management, Spirituality and Religion (JMSR) we could find six articles that explicitly address organizational change or change management. Goltz (2018) frames in an instrumental way the mindfulness practices of Buddhism as "allowing safe space for experiencing the discomfort associated with resistance to change and transcending the discomfort." In a similar instrumental perspective, Geh and Tan (2009, p. 296) see organizational change management as aiming "to help employees meet new and existing performance targets rapidly and effectively" and suggest "that individuals who experience the spiritual foundation of life can grow and develop in ways consistent with organizational goals." In a less instrumental fashion, Whitney (2010, p. 78) explicitly frames Appreciative Inquiry as an organizational change approach that, by creating spiritual resonance in the workplace, "fosters high collaboration, that is collaboration for the greater good, rather than simply collaboration to get the job done." Case and Gosling (2010, p. 259) criticize such instrumental views that "treat spirituality in ahistorical and apolitical terms as yet another neutral resource to be harnessed and husbanded by the erstwhile custodians of organizational performance." Pavlovich (2020, p. 333) offers instead a theorization of "quantum empathy" as "a macrolevel organizing mechanism" based on inner work (mindfulness practices), connectedness (reflexivity), and transcendence (empathy) explicitly not conceived as "a tool-kit for organizational change" but as a spiritual way to reimagine a future beyond exploitative capitalist forms. Groen (2007, p. 310) mentions organizational change management in comparing a religious workplace with a secular one and finds a "remarkable similarity as one considers the various ideals of a spiritually infused workplace, such as vocation, ethics, interconnectedness, and being responsible to our local and global community."

\section{Work Spirituality, Nonhuman Animals and Food}

In the introduction, we anticipated that our focus in this chapter will be the spiritual awakening of millions of children and young adults in science-based social movements. In our own participation in these climate movements we could observe the prevalence of plant-based food as well as the importance of communitarian forms of meditation and getting together linked with a strong longtermist rational orientation. Although we consider the recognition of this expanding moral circle to include future generations and nonhuman animals in non-instrumental ways as a blind spot in the workplace spirituality literature, notwithstanding the above presented 
review of this literature, where concepts such as "ecological sustainability” (Bøje, 2012, p. 520), "transformative connections" with nature (Neal, 2013a, p. 735) and "nonanthropocentric ethics" (Gosling \& Case, 2013) are central, reveals that an integration of a new ethical and spiritual consideration of nonhuman animals should not be a distant call for spirituality scholars.

Indeed, already Neal (2013b, p. 4) refers to the book Blessed Unrest by Paul Hawken (2007, p. 12) who interprets these movements dedicated to creating a sustainable and just world as expressing "the needs of the majority of people on earth to sustain the environment, wage peace, democratize decision making and policy, rejuvenate public governance . . . and improve their lives" (cit. by Stead \& Stead, 2013, p. 273). Neal (2013a, p. 735), in this respect, emphasizes in the concluding chapter of her Handbook the need for the work spirituality field to "seek more transformative connections." In the same place she reports feeling a spiritual connection with nature: "I felt the Earth as a living being, and saw the wind as the breath of Gaia. I felt an overwhelming love for the planet, and suddenly understood why some people were so passionate about sustainability." She ends the chapter with an optimistic referral to Steven Pinker's TED Talk "The Myth of Violence”, where the Harvard professor provides "overwhelming documentation for the decline of violence in humankind” (p. 736). What Neal does not mention is that the end of the talk Pinker introduces Peter Singer's notion of expanding moral circles to include not only future generations but also NHAs: indeed, while violence within humankind has drastically declined especially after WWII, it is exactly in the second half of the past century that intensive animal agriculture in factory farms has emerged, to a point that, according to FAO data, 136 billion farmed NHAs are killed every year after a short and painful life (Elder, 2020, p. 548; Lever \& Evans, 2017).

Before coming back to the theme of the expanding moral circle in the next section, we report here our analysis of how NHAs and, relatedly, food, are considered in the workplace spirituality literature. In Neal's (2013c) Handbook of Faith and Spirituality in the Workplace, we found the word "animal(s)" mentioned only on eight pages in six chapters: as the Jewish mitzvah 'commandment' to be kind to them (Lurie, Ch. 6), as avoiding products that use animal testing and food made with rennet in devotional yoga practice (Greene, Ch. 10), as interconnection in the creation through breath with animals and plants in Maori religiosity (Spiller and Stockdale, Ch. 11), as totemic ancestors and possible entities in which a person's spirit could be reborn in indigenous Australian spirituality (Miley and Read, Ch. 12), as named by Adam (Russel, Ch. 15), and as part of the ecosystem to be included together with plants, waterways and air in the circle of stakeholders of conscious capitalism (Wigglesworth, Ch. 43). Food instead is mentioned on 30 pages: as gratitude for the Chairman of Tyson Foods, one of the world's largest producers of NHA products, as a case study of a Canadian food company selling NHAs product, as ritual practices involving food, as food security and food scarcity, as offer to the needy, and as symbol of gratitude 
and caring. The term "vegetarian" is mentioned only once in the context of devotional yoga practice (Greene, Ch. 10) while "vegan" is never mentioned.

In the Palgrave Handbook of Workplace Spirituality and Fulfillment edited by Dhiman and colleagues (2018), the term "animal*” is mentioned on 21 pages in 14 chapters. Apart from casual mentions such as that of the Oxford English dictionary of the soul as "the principle of life in man or animals" (p. 62), of animal rights in relationship to the pharmaceutical industry (p. 402), or of animals in a zoo, more substantial mentions refer again to the faith-friendly company Tyson Foods and to the religious understandings of the relationship between human and nonhuman animals in Christianity, Buddhism or Hinduism. Dhiman and Kriger (2018, p. 91), for instance, summarize this relationship as follows:

Vedānta promotes harmonious living via a vision of the oneness of all existence. Outwardly, various forms of life such as plants, animals, birds, and human beings seem to be different from one another, but their underlying life principle of pure awareness, the consciousness principle, is one and the same. From the spiritual standpoint, while interacting with the world and the myriad beings, we are to remember that they are all none but our own true Self. If we perceive someone as different from us, we may have aversion or fear, but if we have the vision of oneness, we will see the other as related and just another aspect of our own Self.

Similarly, Pandey and Navare (2018, p. 107) highlight that in yoga humans have an obligation "toward all nonhuman forms of life . . . by protecting them or feeding them . . . where our planet is addressed as mother earth." Maheshwari and Gupta (2018, p. 495) state that the "Vedic scriptures offer a way of harmonious living with other humans, animals, and the cosmos leading to a scenario of all being happy." Interesting is also Burchard's (2018) discussion of the Biblical concept of the gardenerpriest in the chapter Cultivating a Garden of Beauty and Meaning that also includes the reign over animals understood as responsibility. While the terms "vegetarian" and "vegan" are never mentioned in this handbook, the term "food" is mentioned in twenty chapters on 41 pages as offering, ritual gift, shortage, nutrition, fast food, and product of companies.

In the Journal of Management, Spirituality and Religion the search in titles and abstracts for the terms "animal"” and "food" was unsuccessful. Searching everywhere in the text for the term "animal*”, we could find 198 rather casual mentions mainly referring to ritual slaughter, Halal, our purported superiority in dignity to NHAs, but also respect for them. The term "vegetarian" hits four times including Boje's (2005a, 2005b) reporting his conversion to Janisim and to a vegan diet as part of his spiritual journey and Peter Pruzan, interviewed by Laszlo Zsolnai (2019, p. 228), addressing the problem of the incapacity of Western consumers to act on scientific evidence: "the huge consumption of meat is a major contributor to the ongoing disruption of the global climate . . . and the destruction of biotypes $[\ldots$. however] the percentage of the populations in such well-informed societies that are vegetarian or vegan is small." 
We also searched eight bibliographies on the MSR Division Resources Bibliographies and Annotated Bibliographies webpage (https://msr.aom.org/ourlibrary/ new-item) and found only one reference from a search of the words "animal" OR "food" in Rao (no date: 32) Creativity and Personal Mastery. Annotated Bibliography where he mentions Robbins' (2001) book as "a searing indictment of factory farming as well as the treatment of animals generally" and as "mak[ing] the case that our food industry, especially the meat-poultry part of it, is destructive of your health and well-being . . . lay[ing] out economic and environmental reasons for a change in our diet away from animals as food."

Hence, our analysis shows that NHAs have received only scant attention in the workplace spirituality literature and mainly from authors associated with Far Eastern religious traditions. The importance given to the case study of Tyson Foods as a spiritual organization, despite being "the world's largest processor and marketer of chicken, beef, and pork" (2018, p. 29), is significant and evident also in the objectified used of words to denote chickens, cows and pigs. This gap, however, as we have argued at the beginning of this section, could easily be filled as we discuss in the next section.

\section{Expanding the Moral Circle: NHAs As Moral Subjects and Longterminism}

New generations are increasingly involved in movements that question existing economic and social practices because they threaten human and nonhuman survival on this planet. Movements like the youth movement Fridays 4 Future, its adult equivalent Extinction Rebellion, the supportive scientists' movement Scientists 4 Future, to name but a few, are mounting more and more pressure worldwide on political and economic institutions (Etchanchu et al., 2021). In advocating for their own survival and that of future generations as well as for the preservation of biodiversity and the respect for other sentient beings, they expand their moral circle (the circle of beings that demand moral consideration for, both in the dimensions of time, future generations, and of species, nonhuman animals).

"[F]uture generations will outnumber us by thousands or millions to one; of all the people who we might affect with our actions, the overwhelming majority are yet to come. Those people have the same moral value as us in the present. So in the aggregate, their interest matter enormously" (John \& MacAskill, forthcoming, p. 1). The rationale of the idea of longtermism is clear. Future generations of humans will be impacted significantly by our actions (due to climate change, environmental degradation, and depletion of natural resources, for example). John and MacAskill (forthcoming, p. 2) see the root cause of this shortcoming in political short-termism and suggest institutional reforms in order to "increase the time horizons" of governments. 
They propose to install "government research institutions and archivists", "posterity impact assessments”, "future assemblies”, and "legislative houses for future generations” (see also Zsolnai, 2006).

Currently, whether political and economic systems cause future harm or not tends not to be taken into account - at least not enough. Our conduct tends to be morally flawed in the sense that we tend not to extend our moral circle in the temporal dimension. Moreover, we tend to exclude those who do not belong to our own species, and thus cause considerable harm and suffering. Peter Singer (2011, p. 120) is a famous voice in the philosophic ethics discourse calling for an inclusion of NHAs into our moral circle. He points out that "the pleasures and pains of nonhuman animals are no less significant because the animals are not members of the species Homo sapiens."

The practices we observed in our individual experiences in the social movements trying to expand our moral circles in the temporal and species dimensions seem consistent with the ethical idea of expanding our moral circle. We observed meditation and mindfulness derived from the Buddhist meditation tradition, but also forms of religious syncretism and shamanism (as in the Signal group "Spirit of XR” where spirituality is discussed also in 'secular' terms). The sharing of vegetarian or vegan food (even freegan meals recovered from food items others would have or have thrown out) is also a central component in communitarian gatherings as well as rituals of so-called "check-ins" and "check-outs" in which activists not only share a meal but also their current personal emotional states in order round off their activities with a further communitarian aspect. This combination of mindfulness and communitarian values confirms the different meanings that such practices have in these movements in comparison to the more individualist reception of yoga and New Age meditation in older generations (Munir et al., 2021). Indeed, du Plessis and Just (2021) see in the recent reception of mindfulness in these movements a transformative and progressive potential. Moreover, these practices and the strong values of respect for nature and compassion for all sentient beings are not combined with irrational beliefs, but, paradoxically, with beliefs in rational scientific principles - an observation that confirms Taylor and Bell's (2012, p. 576) reflection that contemporary spiritualities enable individuals "to reconcile reason and emotion," relationality and critical thinking (to be sure, not a totally new phenomenon, as also Christian philosophers like Thomas Aquinas based faith on reason). In other words, in these, “[t]he experience of a transformative connection” (Lurie, 2013, p. 91) assumes a different spiritual form. 


\section{Conclusions}

In this chapter we have argued that (critical) work spirituality studies should extend their understanding of spirituality to encompass more philosophical valuebased approaches that argue for the expansion of our moral circle. It is worth taking note of the diffusion of science-based practices of meditation and community in social movements where millions of young and less-young people are socialized to political life and action. Because a new relationship with NHAs considered as sentient beings is central in this new rational spiritual orientation, our academic understanding of NHAs and organizational practices towards them will have to be rethought completely. Organizations will be flooded by this new generation and will have to react in many ways if they want to maintain their legitimacy. The decision if we should completely abolish NHA farming and all go vegan or if we should 'only' drastically reduce meat and dairy consumption and resort for the rest to high-welfare small-scale NHA agriculture (Bruckner, 2020) and to cultured meat ${ }^{1}$ and dairy (Elder, 2020) is still debated also with reference to geographical and socio-economic conditions (Smith, 2016; Jairath et al., 2021). However, factory farms are the source of 99 percent of NHA products in industrial societies (Lever \& Evans, 2017). Those places, in which profitability rather than animal welfare is prioritized, undoubtedly represent the dark side of human mastery of nature. The appalling suffering in slaughterhouses and factory farms should provide us with ample reason to expand our moral circle to include nonhuman sentient beings. As is emphasized in the ethical stance of longtermism, next to nonhumans, also the fate of future generations of humans depends on our ethical conduct. We'd like to conclude this chapter with Judi Neal's (2013c) opening longtermist dedication in her Handbook: "May the work that we are doing today help create a better world for you and for at least seven generations."

\footnotetext{
1 Interestingly, Tyson Foods has recently diversified its lines of business and has invested in the development of zero-suffering alternative proteins like plant-based and cultured meat. Tom Hayes, President and Chief Executive Officer at Tyson Foods, framed this move not as an "either or" but as a "yes and" scenario (2018) focusing on the growing need of sustainable proteins for a growing world population. No mention is made of farm animal welfare as a motivation. The company slaughters approximately 155,000 cows, 461,000 pigs and 45,000,000 chickens every week (Tyson Sustainability Report 2019, 2019, https://www.tysonsustainability.com/downloads/Tyson_2019_Sus tainability_Report.pdf, accessed 24 March 2021).
} 


\section{References}

Benn, S., \& Baker, E. (2009). Advancing sustainability Through change and innovation: A Co-evolutionary perspective. Journal of Change Management, 9(4), 383-397. https://doi. org/10.1080/14697010903360574

Bøje, D. M. (2012). Reflections: What does quantum physics of storytelling mean for change management? Journal of Change Management, 12(3), 253-271. https://doi.org/10.1080/ 14697017.2011.609330

Bøje, D. M. (2005b). Epilogue: Critical spirituality. Journal of Management, Spirituality \& Religion, 2(3), 399-405. https://doi.org/10.1080/14766080509518600

Bøje, D. M. (2005a). Wilda. Journal of Management, Spirituality \& Religion, 2(3), 342-364. https:// doi.org/10.1080/14766080509518592

Bøje, D. M., Burnes, B., \& Hassard, J. (Eds.). (2012). The Routledge Companion to Organizational Change (0 ed.). Routledge. https://doi.org/10.4324/9780203810279

Bucci, J. J. 2018. Change Management: Considering a Peniel Approach for Managing Change in Organizations. In The Palgrave Handbook of Workplace Spirituality and Fulfillment (pp. 943-968). Palgrave Macmillan. https://doi.org/10.1007/978-3-319-62163-0

Bruckner, D. W. (2020). Small-scale animal agriculture. In B. Fischer (Ed.), The Routledge Handbook of Animal Ethics (pp. 198-210). Routledge.

Burchard, M. J. (2018). Cultivating a garden of beauty and meaning: Organizational spirituality's restorative mission from a theological, scientific, and aesthetic perspective. In G. E. Roberts \& J. E. Crossman (Eds.), The Palgrave Handbook of Workplace Spirituality and Fulfillment (pp. 345-365). Palgrave Macmillan. https://doi.org/10.1007/978-3-319-62163-0_13

Burton, O., Jeong, S., \& Saini, K. M. (2018). Dark spirituality: Its impact on the strategic and operational efficiency of organizations. In G. E. Roberts \& J. E. Crossman (Eds.), The Palgrave Handbook of Workplace Spirituality and Fulfillment (pp. 969-987). Palgrave Macmillan. https://doi.org/10.1007/978-3-319-62163-0_36

Bushe, G. R. (2012). Appreciative inquiry: Theory and critique. In D. M. Freidenreich, B. Burnes, \& J. Hassard (Eds.), The Routledge Companion To Organizational Change (pp. 87-103). Routledge.

Case, P., \& Gosling, J. (2010). The spiritual organization: Critical reflections on the instrumentality of workplace spirituality. Journal of Management, Spirituality \& Religion, 7(4), 257-282. https://doi.org/10.1080/14766086.2010.524727

Dehler, G. E., \& Welsh, M. A. (1994). Spirituality and Organizational Transformation: Implications for the New Management Paradigm. Journal of Managerial Psychology, 9(6), 17-26. https:// doi.org/10.1108/02683949410070179

Dent, E. B., Higgins, M. E., \& Wharff, D. M. (2005). Spirituality and leadership: An empirical review of definitions, distinctions, and embedded assumptions. The Leadership Quarterly, 16(5), 625-653. https://doi.org/10.1016/j.leaqua.2005.07.002

Dhiman, S., \& Kriger, M. (2018). Eastern approaches to organizational well-being: Ontological levels of leadership in Hinduism, Buddhism, and Taoism. In S. Dhiman, G. E. Roberts, \& J. E. Crossman (Eds.), The Palgrave Handbook of Workplace Spirituality and Fulfillment. Palgrave Macmillan. https://doi.org/10.1007/978-3-319-61929-3_2-1

Dhiman, S., Roberts, G. E., \& Crossman, J. E. (2018). The Palgrave Handbook of Workplace Spirituality and Fulfillment. Palgrave Macmillan.

du Plessis, E. M., \& Just, S. N. (2021). Mindfulness - it's not what you think: Toward critical reconciliation with progressive self-development practices. Organization, 13. https://doi.org/ $10.1177 / 1350508421995755$ 
Elder, M. (2020). Cultured meat. In B. Fischer (Ed.), The Routledge Handbook of Animal Ethics. Routledge.

Etchanchu, H., de Bakker, F., \& Delmestri, G. (2021). Social movement organizations' agency for sustainable organizing. In S. Teerikangas, T. Onkila, K. Koistinen, \& M. Mäkelä (Eds.), Research Handbook of Sustainability Agency (pp. 194-210). Edward Elgar.

Fischer, B. (2020). The Ethics of Eating Animals: Usually Bad, Sometimes Wrong, Often Permissible. Routledge.

Fowler, J. W. (1981). Stages of Faith: The Psychology of Human Development and the Quest for Meaning (1st ed). Harper \& Row.

Geh, E. Z., \& Tan, G. (2009). Spirituality at work in a changing world: Managerial and research implications. Journal of Management, Spirituality \& Religion, 6(4), 287-300. https://doi.org/ $10.1080 / 14766080903290093$

Gill, R. (2002). Change management - Or change leadership? Journal of Change Management, 3(4), 307-318. https://doi.org/10.1080/714023845

Goltz, S. M. (2018). Organizational change: Insights from Buddhism and Acceptance and Commitment Therapy(ACT). Journal of Management, Spirituality \& Religion, 15(5), 424-449. https://doi.org/10.1080/14766086.2018.1513857

Goodhart, C., \& Pradhan, M. (2017). Demographics will reverse three multi-decade global trends (BIS Working Paper No. 656 No. 656). Bank for International Settlements. https://ssrn.com/ abstract $=3015065$

Gosling, J., \& Case, P. (2013). Social dreaming and ecocentric ethics: Sources of non-rational insight in the face of climate change catastrophe. Organization, 20(5), 705-721. https:// doi.org/10.1177/1350508413489814

Groen, J. (2007). Spirituality within a religious workplace: Is it so different? Journal of Management, Spirituality \& Religion, 4(3), 310-325. https://doi.org/10.1080/ 14766080709518667

Hawken, P. (2007). Blessed Unrest: How the Largest Social Movement in History Is Restoring Grace, Justice, and Beauty to the World. Viking Press.

Hayes, T. (2018, January 29). Why we are investing in alternative proteins. https://thefeed.blog/ 2018/01/29/why-we-are-investing-in-alternative-proteins/

Jairath, G., Mal, G., Gopinath, D., \& Singh, B. (2021). A holistic approach to access the viability of cultured meat: A review. Trends in Food Science \& Technology, 110, 700-710. https://doi.org/ 10.1016/j.tifs.2021.02.024

John, T., \& MacAskill, W. (forthcoming). Longtermist institutional reform. In N. Cargill \& T. M. John (Eds.), The Long View. FIRST.

Kawall, J. (2003). Reverence for life as a viable environmental virtue. Environmental Ethics, 25(4), 339-358. https://doi.org/10.5840/enviroethics20032542

Kühl, S. (2020). The blind spots in theory U: The reconstruction of a (change-) management fashion. Journal of Change Management, 20(4), 314-321. https://doi.org/10.1080/ 14697017.2020.1744883

Lever, J., \& Evans, A. (2017). Corporate social responsibility and farm animal welfare: Towards sustainable development in the food industry? In S. O. Idowu \& S. Vertigans (Eds.), Stages of Corporate Social Responsibility (pp. 205-222). Springer International Publishing. https://doi. org/10.1007/978-3-319-43536-7_10

Long, B. S., \& Mills, H. J. (2010). Workplace spirituality, contested meaning, and the culture of organization: A critical sensemaking account. Journal of Organizational Change Management, 23(3), 325-341. https://doi.org/10.1108/09534811011049635 
Lurie, A. (2013). Faith and spirituality in the workplace: A Jewish perspective. In J. Neal (Ed.), Handbook of Faith and Spirituality in the Workplace. Emerging Research and Practice (pp. 85-101). Springer. https://doi.org/10.1007/978-1-4614-5233-1_6

Mabey, C., \& Mayrhofer, W. (2015). What Kind of Leader Are You Becoming? In C. Mabey \& W. Mayrhofer (Eds.), Developing Leadeship. Questions Business Schools Don't Ask (pp. 1-28). Sage.

Maheshwari, A. K., \& Gupta, R. K. (2018). Vedic leadership: Theory and practice of operating from natural law. In G. E. Roberts \& J. E. Crossman (Eds.), The Palgrave Handbook of Workplace Spirituality and Fulfillment (pp. 491-511). Palgrave Macmillan. https://doi.org/10.1007/978-3319-62163-0_57

Major, R. (2013). Workplace spirituality as an aggregate construct of organizational theory concepts: Shutting down Hewlett-Packard's volume systems division. In J. Neal (Ed.), Handbook of Faith and Spirituality in the Workplace (pp. 519-534). Springer. https://doi.org/ 10.1007/978-1-4614-5233-1_30

Mitroff, I. I., \& Denton, E. A. (1999). A study of spirituality in the workplace. MIT Sloan Management Review, 40(4), 83-92.

MSR Division. (2018). Annotated list of workplace spirituality organizations. Management, Spirituality \& Religion Division, Academy of Management. https://msr.aom.org/ourlibrary/ workplacespirituality

Munir, K., Ansari, S. (Shaz), \& Brown, D. (2021). From Patañjali to the "gospel of sweat": Yoga's remarkable transformation from a sacred movement into a thriving global market. Administrative Science Quarterly, 1-46. https://doi.org/10.1177/0001839221993475

Neal, J. (2018). Overview of workplace spirituality research. In S. Dhiman, G. E. Roberts, \& J. E. Crossman (Eds.), The Palgrave Handbook of Workplace Spirituality and Fulfillment (pp. 1-56). Palgrave Macmillan. https://doi.org/10.1007/978-3-319-61929-3_45-1

Neal, J. (2013a). Epilogue: Where do we go from here? In J. Neal (Ed.), Handbook of Faith and Spirituality in the Workplace (pp. 733-739). Springer. https://doi.org/10.1007/978-1-46145233-1_44

Neal, J. (2013b). Faith and spirituality in the workplace: Emerging research and practice. In J. Neal (Ed.), Handbook of Faith and Spirituality in the Workplace: Emerging Research and Practice (pp. 3-18). Springer. https://doi.org/10.1007/978-1-4614-5233-1_1

Neal, J. (Ed.). (2013c). Handbook of Faith and Spirituality in the Workplace: Emerging Research and Practice. Springer.

Pandey, A., \& Navare, A. V. (2018). Paths of yoga: Perspective for workplace spirituality. In G. E. Roberts \& J. E. Crossman (Eds.), The Palgrave Handbook of Workplace Spirituality and Fulfillment (pp. 101-126). Palgrave Macmillan. https://doi.org/10.1007/978-3-319-62163-0_4

Pavlovich, K. (2020). Quantum empathy: An alternative narrative for global transcendence. Journal of Management, Spirituality \& Religion, 17(4), 333-347. https://doi.org/10.1080/ 14766086.2019.1706626

Poole, M. S., \& Van de Ven, A. H. (2004). Handbook of Organizational Change and Innovation. Oxford University Press. https://books.google.at/books?id=Pu-vw387jmkC

Porras, J. I., \& Silvers, R. C. (1991). Organization development and transformation. Annual Review of Psychology, 42(1), 51-78. https://doi.org/10.1146/annurev.ps.42.020191.000411

Pruzan, P., \& Zsolnai, L. (2019). An interview with Peter Pruzan on spiritual transformation in management. Journal of Management, Spirituality \& Religion, 16(2), 221-230. https://doi.org/ $10.1080 / 14766086.2018 .1548972$

Robbins, J. (2001). The Food Revolution: How Your Diet Can Help Save Your Life and Our World. Conari Press. 
Roberts, G. E., Crossman, J. E., \& Bucci, J. J. (Eds.). (2018). Change management: Considering a peniel approach for managing change in organizations. In The Palgrave Handbook of Workplace Spirituality and Fulfillment (pp. 943-968). Palgrave Macmillan. https://doi.org/ 10.1007/978-3-319-62163-0

Russell, M. L. (2013). The secret of leadership success. In J. Neal (Ed.), Handbook of Faith and Spirituality in the Workplace: Emerging Research and Practice (pp. 237-254). Springer. https://doi.org/10.1007/978-1-4614-5233-1_15

Scharmer, O. (2020). Social systems as if people mattered response to the Kühl critique of theory U. Journal of Change Management, 20(4), 322-332. https://doi.org/10.1080/ 14697017.2020.1744884

Schweitzer, A. (1947). The Spiritual Life: Selected Writings of Albert Schweitzer; Edited by Charles $R$. Joy; Introduction by Robert Coles \& Bob Kerrey.

Singer, P. (2011). The Expanding Circle: Ethics, Evolution, and Moral Progress. Princeton University Press. https://books.google.at/books?id=Yve7lgvtLcsC

Smith, A. F. (2016). A Critique of the Moral Defense of Vegetarianism. Palgrave Macmillan. https:// books.google.at/books?id=duOYDAAAQBAJ

Stead, W. E., \& Stead, J. G. (2013). Green man rising: Spirituality and sustainable strategic management. In J. Neal (Ed.), Handbook of Faith and Spirituality in the Workplace (pp. 271-283). Springer. https://doi.org/10.1007/978-1-4614-5233-1_17

Stoner, J. A. F. (2013). Creating a spiritually friendly company. In J. Neal (Ed.), Handbook of Faith and Spirituality in the Workplace: Emerging Research and Practice (pp. 491-517). Springer. https://doi.org/10.1007/978-1-4614-5233-1_29

Taylor, S., \& Bell, E. (2012). The promise of re-enchantment. Organizational culture and the spirituality at work movement. In D. M. Bøje, B. Burnes, \& J. Hassard (Eds.), The Routledge Companion to Organizational Change (0 ed., pp. 568-579). Routledge. https://doi.org/ $10.4324 / 9780203810279$

Tyson Sustainability Report 2019. (2019). https://www.tysonsustainability.com/downloads/Tyson_ 2019_Sustainability_Report.pdf

Waddock, S. (2015). Intellectual Shamans: Management Academics Making a Difference. Cambridge University Press. https://books.google.at/books?id=a8WTBQAAQBAJ

Waddock, S., \& Steckler, E. (2013). Wisdom, spirituality, social entrepreneurs, and self-sustaining practices: What can we learn from difference makers? In J. Neal (Ed.), Handbook of Faith and Spirituality in the Workplace: Emerging Research and Practice (pp. 285-301). Springer. https://doi.org/10.1007/978-1-4614-5233-1_18

Whitney, D. (2010). Appreciative inquiry: Creating spiritual resonance in the workplace. Journal of Management, Spirituality \& Religion, 7(1), 73-88. https://doi.org/10.1080/ 14766080903497656

Willett, W., Rockström, J., Loken, B., Springmann, M., Lang, T., Vermeulen, S., Garnett, T., Tilman, D., DeClerck, F., Wood, A., Jonell, M., Clark, M., Gordon, L. J., Fanzo, J., Hawkes, C., Zurayk, R., Rivera, J. A., De Vries, W., Majele Sibanda, L., . . . Murray, C. J. L. (2019). Food in the anthropocene: The EAT-Lancet Commission on healthy diets from sustainable food systems. The Lancet, 393(10170), 447-492. https://doi.org/10.1016/S0140-6736(18)31788-4

Zohar, D., \& Marshall, I. N. (2004). Spiritual Capital: Wealth We Can Live by. Bloomsbury. https:// books.google.at/books?id=205pPwAACAAJ

Zsolnai, L. (2006). Extended stakeholder theory. Society and Business Review, 1(1), 37-44. https:// doi.org/10.1108/17465680610643337 
